\title{
THE PRINCIPLES OF SUSTAINABLE DEVELOPMENT OF TOURISM IN THE SPECIAL NATURE RESERVE »GORNJE PODUNAVLJE« AND THEIR IMPACT ON THE LOCAL COMMUNITIES
}

Vladimir Stojanović, Jasmina Đorđević, Lazar Lazić, Igor Stamenković, Vanja Dragićević

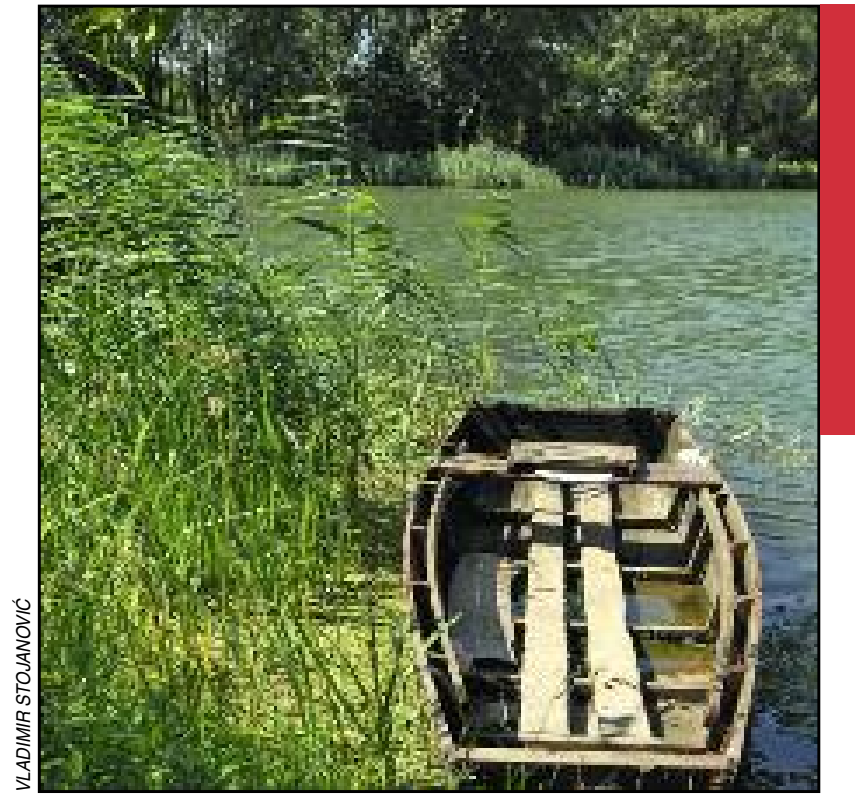

Special Nature Reserve Gornje Podunavlje near Bezdan. 


\title{
The principles of sustainable development of tourism in the special nature reserve »Gornje Podunavlje« and their impact on the local communities
}

\author{
DOI: http://dx.doi.org/10.3986/AGS54407 \\ UDC: $913: 338.48(497.113)$ \\ $338.48: 712(497.113)$ \\ COBISS: 1.01
}

\begin{abstract}
:
The development of tourism in protected areas is a particular challenge for the tourism business and the activity of nature conservation. The leading criteria for sustainable tourism in protected areas emphasize the importance of the adoption of certain principles of care, long-term planning and management that integrates nature protection and tourism. In this respect, the paper analyzes their importance in the case of Special Nature Reserve »Gornje Podunavlje « in Vojvodina. After acquiring the status of a special nature reserve, talk about the importance of this area to the tourism of Sombor and Apatin, where it is located, has increased. This trend follows the design of educational and tourist tracks, starting and running events as well as starting tourism businesses in rural households. There could be multiple benefits of this for the local communities.
\end{abstract}

KEY WORDS: geography, sustainable development, tourism, protected area, Gornje Podunavlje, local communities

The article was submitted for publication on December 20, 2012.

ADDRESSES:

Vladimir Stojanović, Ph. D.

Department of Geography, Tourism and Hotel Management

Faculty of Sciences

University of Novi Sad

Trg Dositeja Obradovića 3, 21000 Novi Sad, Serbia

E-mail: vladimir.stojanovic@dgt.uns.ac.rs

Jasmina Đorđević, Ph. D.

Department of Geography, Tourism and Hotel Management

Faculty of Sciences

University of Novi Sad

Trg Dositeja Obradovića 3, 21000 Novi Sad, Serbia

E-mail: jasmina.djordjevic@dgt.uns.ac.rs

Lazar Lazić, Ph. D.

Department of Geography, Tourism and Hotel Management

Faculty of Sciences

University of Novi Sad

Trg Dositeja Obradovića 3, 21000 Novi Sad, Serbia

E-mail: lazarus@eunet.rs

Igor Stamenković, Ms.Sc.

Department of Geography, Tourism and Hotel Management

Faculty of Sciences

University of Novi Sad

Trg Dositeja Obradovića 3, 21000 Novi Sad, Serbia

E-mail: igor.stamenkovic@dgt.uns.ac.rs 
Vanja Dragićević Ph. D.

Department of Geography, Tourism and Hotel Management

Faculty of Sciences

University of Novi Sad

Trg Dositeja Obradovića 3, 21000 Novi Sad, Serbia

E-mail:drvanja@yahoo.com 


\section{Introduction}

Tourism can change the communities of the local population, either positively or negatively (Fennel 1999). Tourism is on the one hand to provide employment, increase the level of participation in local events and decisions (Holden 2000), it is to provide the possibility to present traditions and culture which until tourism development has not had a »critical mass", and it is to increase funding for the preservation of monuments and traditions and the democratization of culture (Hadžić 2005). On the other hand, tourism can commercialize tradition and popular culture, even those events that are of emotional or personal nature (Hall and Page 2002).

Tourism and environmental protection are multiply connected, among other things, through the concept of the ecological, economic and social benefits and analysis of the influence. Valorisation and analysis of influences within these three areas is present and important for the modern concept of protection (Prato and Fagre 2005), but also for tourism (Fennel 1999). Tourism in protected areas can unite all three concepts - protection, economic income and social wellbeing of the local population. The concept of sustainable tourism in protected areas is based on this principle.

Special Nature Reserve »Gornje Podunavlje« is a protected natural resource in the northwestern part of Serbia, in the Autonomous Province of Vojvodina. This paper is based on defined principles of sustainable tourism in protected areas and through a comparative analysis, based on field research, it examines how much these principles are actually present in the Special Nature Reserve Gornje Podunavlje and its environs.

\section{Protection of nature as a condition for tourism development of Gornje Podunavlje}

The principle of protection is one of the necessary conditions for sustainable development of tourism (Jovičić 2001). Such a tendency can be seen as one way of achieving the general objectives of sustainable development. It is assumed that the states and regions that have a higher percentage of protected territories, provided that protection is real and not declarative, are also more likely to meet the standards for sustainable development of tourism (Mowforth and Munt 2003). A good way to meet the principles of protection is the use of sustainable tourism indicators (Indicators of Sustainable Development for Tourism Destinations 2004).

Protection of Gornje Podunavlje has a long chronology. The whole area was protected, roughly in its current size, in 1982 as a regional park based on the opinion of the Provincial Institute for Nature Conservation. The decision was implemented by the municipalities of Sombor and Apatin. Gornje Podunavlje was finally declared a Special Nature Reserve in 2001. Special Nature Reserve »Gornje Podunavlje« has international protection as well. The Ramsar area Gornje Podunavlje was put on the list of Ramsar areas in 2007.

Table 1: The existing criteria for sustainable tourism in the Special Nature Reserve Gornje Podunavlje.

\begin{tabular}{lll}
\hline Principles & Planning & Management \\
\hline - Protection Department in the Sombor & - Regulation on the Protection of & - Protection Department at FMU Sombor \\
Forest Estate (Vojvodinašume) & the Special Nature Reserve & - Protection sector in Vojvodinašume \\
- Promotion of protection & pGornje Podunavlic company \\
through the website & - Annual programs and ten-year & - Provincial Institute for Nature Protection \\
(http://www.gornjepodunavlje.info/); & management plan; & - Provincial Secretariat for Environmental \\
- Promotion through the creation & - The Spatial plan PPN of the Special & Protection \\
of tourist-educational tracks & Nature Reserve Gornje Podunavlje; & - Ministry of Energy, Development \\
- The marking of protected areas & - The Regional Spatial Plan of AP & and Environmental Protection of \\
through information boards at & Vojvodina, from 2009. to 2020; & the Republic of Serbia. \\
the entrance and other places & - Master plan for the tourist destination & \\
- Codes of conduct on boards at & Gornje Podunavlje, 2007; & \\
the entrance to the Reserve & - Feasibility study of development & \\
& of eco-tourism in protected areas & \\
& of Vojvodina. & \\
& &
\end{tabular}




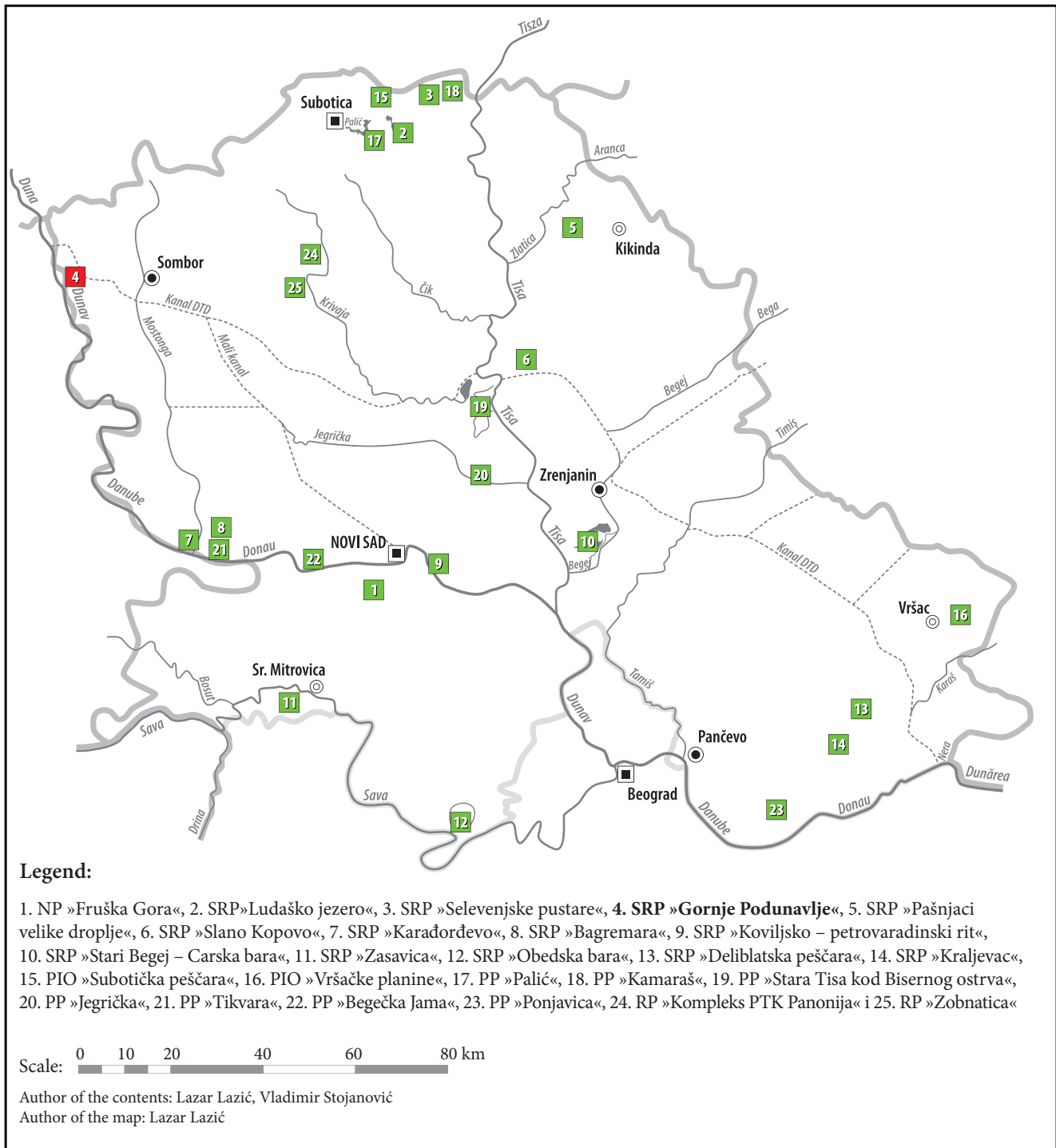

Figure 1: Location of the Special Nature Reserve »Gornje Podunavlje« in the system of protected areas in Vojvodina.

In recent years, the development of eco-tourism is linked to the formation of specific products. Attempts of development of ecotourism are linked to the formation of educational tracks of which the Special Nature Reserve has three: Circular Karapandža educational track $(3 \mathrm{~km})$; Educational track Bestrement $(3 \mathrm{~km})$ and Educational track Štrbac $(2 \mathrm{~km})$. Information boards not only introduce visitors to the field of information about basic resources, but also present specific measures and protection programs. So on the Štrbac trail, visitors are given a detailed introduction into the process of revitalization of degraded salt marshes by removing shrubby vegetation, in order to restore the mosaic of the ecosystem and landscape beauty (Figure 2).

There are currently a wide range of criteria that explain how it is necessary that tourism is related to sustainable development and environmental protection. This primarily involves the principles, planning and management (Boyd 2000). The principles include impartiality, ethical principles, the use of carrying 
capacity and the promotion of protection. Planning must be long-term, proactive, integrated and must involve the local population. Management includes responsibility and integration of tourism with other users of the area. By analyzing such a concept we perceive some advantages that Special Nature Reserve »Gornje Podunavlje« has as a destination of ecotourism and nature conservation (Table 1).

\section{Impact of ecotourism of Gornje Podunavlje on the local communities surrounding the reserve}

In the villages surrounding the reserve there are 85,444 people (Popis stanovništva, domaćinstava i stanova u Republici Srbiji 2011 - prvi rezultati 2011), in seven villages (Bački Breg, Kolut, Bezdan, Bački Monostor, Kupusina, Svilojevo and Sonta) and two towns (Sombor and Apatin). Similar to other border settlements of Vojvodina the area is characterized by depopulation, emigration to large urban centers and the aging of the population (Ivkov-Džigurski et al. 2010). This predominantly rural area in addition to the many problems of everyday life is also burdened with issues related to the sense of living in the villages, the affirmation of cultural identity and its presentation (Blešić et al. 2014). Can eco-tourism and rural tourism offer a solution to the existing problems?

So far, the impact of nature on villages around the Reserve Gornje Podunavlje was most prominent in the area of affirmation of cultural heritage and the development of awareness of cultural identity and pride in being one of the key factors of sustainable development and ecotourism. Local heritage can be analyzed through the list of protected monuments in the area of Special Nature Reserve Gornje Podunavlje. In the registered settlements, 39 cultural monuments, places of interest, geographical cultural and historical sites have been documented (Folić - Kurtović et al. 2008). These include churches, chapels, homes of famous people, houses as valuable architectural monuments, a castle and two town cores. Some of them are well known from before, for example, the protected town cores of Sombor and Apatin. Those environmental

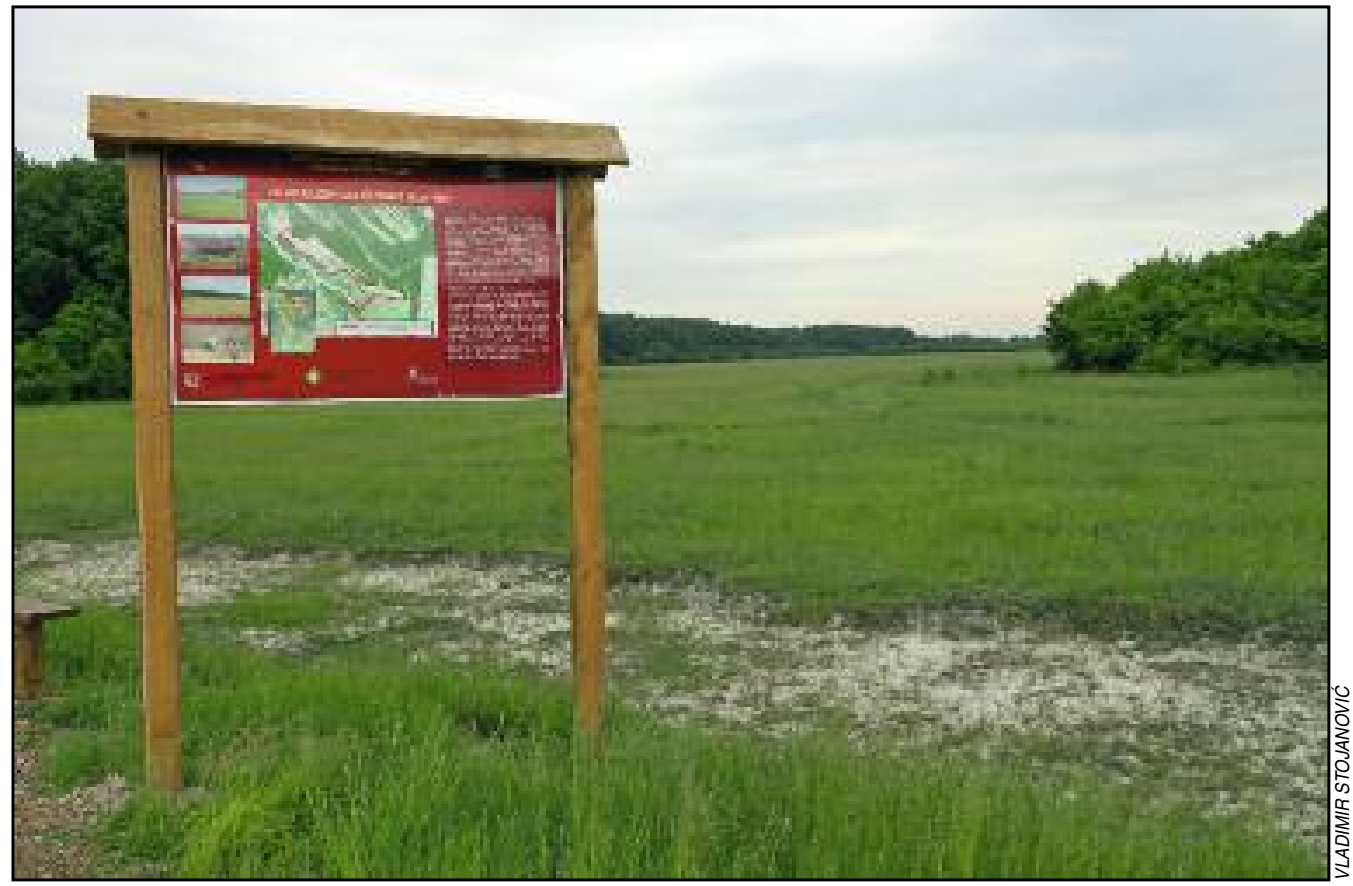

Figure 2: Štrbac Locality including the endangered salt marshes, the revitalization of which visitors are informed on, through information boards. 


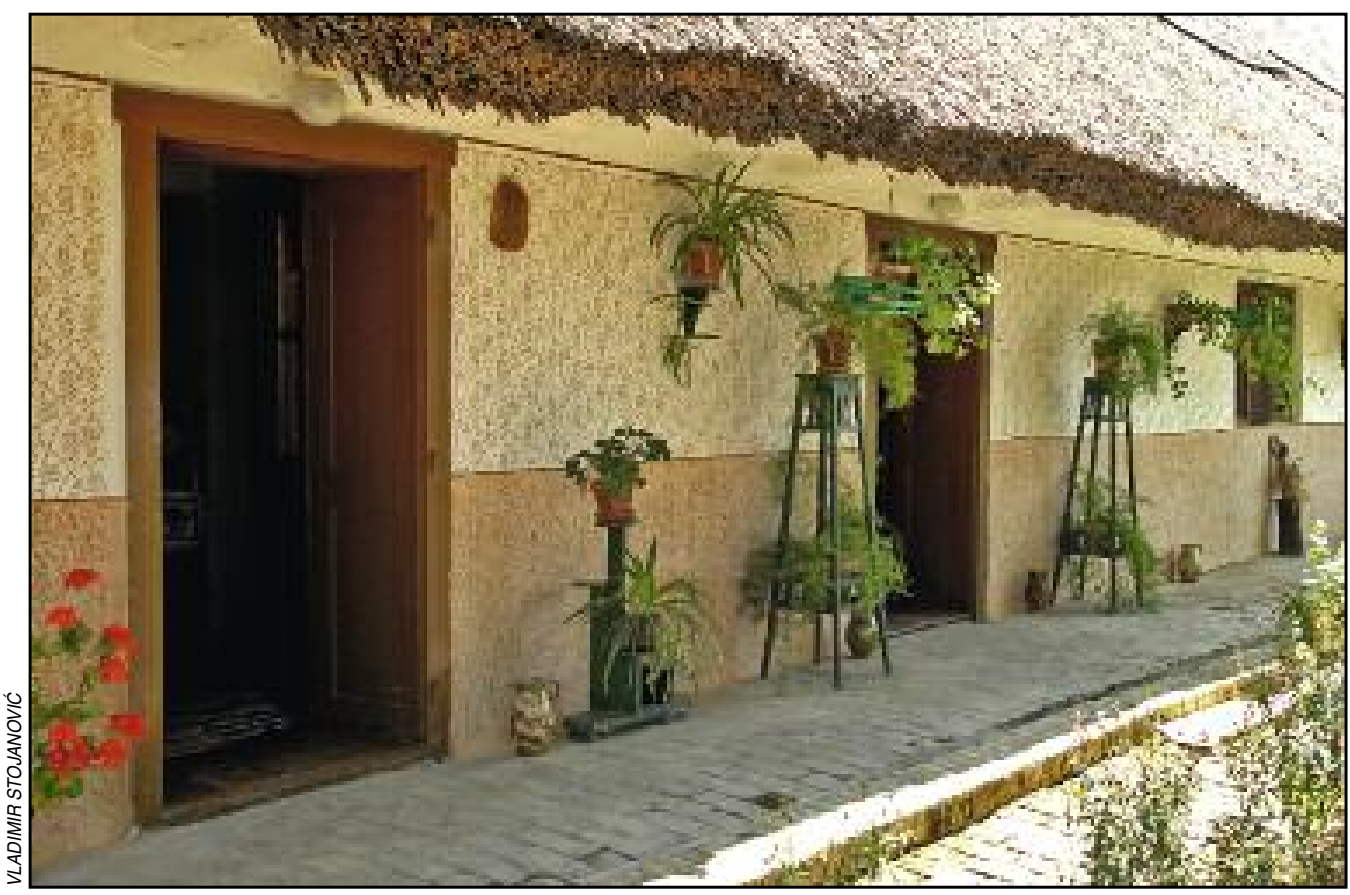

Figure 3: Ethno-house Bodrog in Bački Monoštor.

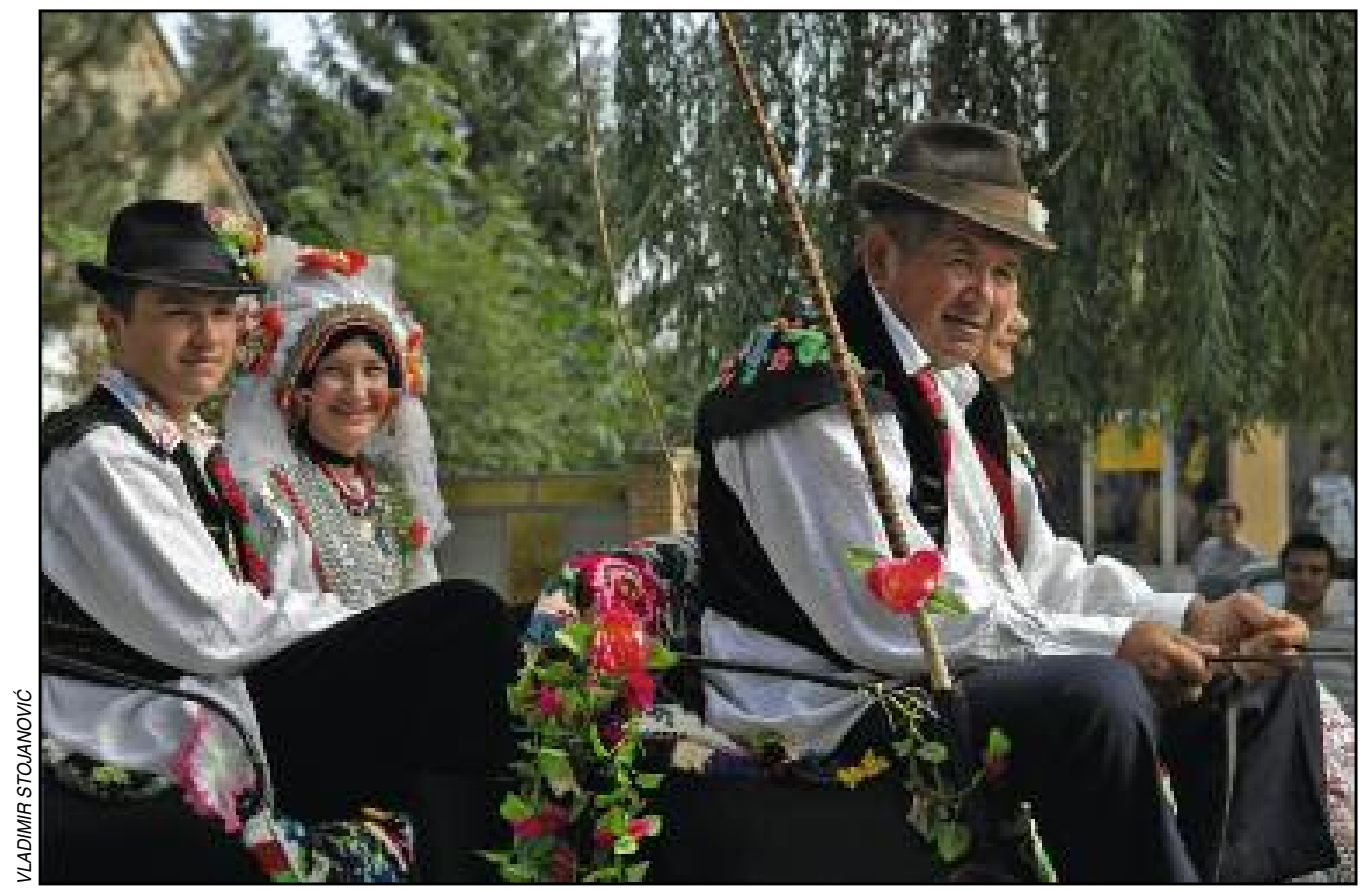

Figure 4: The event of grape harvesting festival with an imitation of a traditional Šokci wedding is one of the important potentials of ecotourism and rural tourism of Gornje Podunavlje. 
entities have been beautifully decorated with the function of tourism development for some time. However, other resources have been established due to nature protection in the reserve. The story of Nature Protection motivated the local people to think about new development opportunities through the development of tourism. These other resources, those that are not under some kind of declarative protection of cultural heritage, make the destination distinctive, special and their identification is essential for paving the way for sustainable development of tourism, which is, after all, stated in guides for Sustainable Tourism Development.

The village of Bački Monostor had no accommodation units in rural tourism before the declaration of the reserve, and now 15 households are involved in the business. After the declaration of the reserve two ethno-houses were opened in the village. Ethno-house Kuveljić was opened on the banks of the river branch and presents a traditional household engaged in fishing. Ethno-house Bodorg is located in the center of the village and presents traditional household furniture from Monoštor (Figure 3). Bodrog Fest has been taking place since 2005. as a festival of tradition, music, food and old crafts. It was created as part of promotion of resources of Gornje Podunavlje and its environment, and its basic task is to promote nature protection. In previous years the program presented activities that are directly related to the protection of nature in the reserve - opening the gates of Gornje Podunavlje, placing information boards and creating tourist routes. Bački Monoštor has not only presented itself as the leader in the tourist offer throughout the region, but also in activities that were focused on education for rural tourism and ecotourism.

Recognition and promotion of the Special Nature Reserve resulted in similar processes in other nearby villages. In Bezdan the ethno-house Jelena with about 1,000 exhibits was opened. It is not uncommon that some are up to 150 years old. In the southern part the ethno-house in Kupusina stands out, which, with its three rooms symbolically represents a typical old house of this region. It also holds the record for the largest share of foreign tourists, mainly from Hungary, which is not surprising, considering the fact that it presents a traditional Hungarian household. The oldest artifact in the collection - a girl's cabinet, dates back to 1817 (Tomić et al. 2002). The equipping and opening of an ethno-house in Sonta is pending. This village with the event of grape harvesting festival (Figure 4), one of the oldest in Vojvodina since it has been continuously held since 1928, is one of the most valuable resources in the Gornje Podunavlje Reserve area (Stojanović 2005).

The process of promotion of local folk heritage described in several previous examples is independent. It originated mainly from the local community over the past ten years and has accompanied the promotion of the protection of the Reserve »Gornje Podunavlje«. The essential flaw in this kind of phenomenon of affirmation of local heritage is that it was haphazardly and often without the support of experts - ethnologists, tourism managers, or geographers, and it often happens that a set of different values, tangible or intangible is not properly promoted and presented. Another problem is the lack of clear coordination among stakeholders of the cultural offer in different villages, so there are no unique itineraries or thematic routes. Given that these kinds of initiatives are commonplace in rural tourism and bring results (Roberts and Hall 2003), they should be started here as well. Finally, the tangible and intangible heritage of these villages must be viewed through the prism of rural capital - the traditional physiognomy and morphology of villages, customs, culture, folk art, all of these are valuable assets in the development of tourism. This is precisely what the experience that tourists will take home with them depends on (Garrod, Wornell and Youell 2006; Todorović and Bjeljac 2009). In such a value system, erosion of cultural heritage will not happen.

As a means of paving the way for development of sustainable tourism we can use a list of resources that can help the development of principles of this type of tourism (Mowforth and Munt 2003) and in this sense, for each of the eight groups, there are certain advantages and disadvantages (Table 2).

Sustainable development of tourism in Gornje Podunavlje should be significantly improved by the status of Biosphere Reserve, which is expected in the near future. The benefit of the declaration of Biosphere Reserve could be even greater. The reserve is designed as an internationally protected area including the the valleys of Mura, Drava and Danube rivers, including border areas of five countries: Austria, Slovenia, Hungary, Croatia and Serbia. Tourism market trends favor this, because the essence of tourist attraction of international, "parks « is the fact that the boundaries and border areas become important tourist destinations. This is because they include multiple countries, different social systems and cultural circles (Timothy 2000). The advantage of these trends, has been noticed by the authors of the Croatian and Hungarian text of nomination for the future Biosphere Reserve, so similar initiatives are emphasized here as well. 
Table 2: Means of implementation of sustainable tourism of Gornje Podunavlje with the list of advantages and disadvantages.

\section{Protection of the area}

Advantages:

- $12.84 \%$ of the total common area of Sombor and Apatin goes to the Special Nature Reserve »Gornje Podunavlje

- The tradition of protection in the form of other categories

- International Status (IBA, Ramsar)

- The procedure for the declaration of Biosphere Reserve (MAB)

Disadvantages:

- Favouring the economic principle of protected area management (forestry, fishing, hunting).

- Lack of encouragement of ecotourism as an important tool for the protection of nature

\section{Regulation of the tourism industry}

\section{Advantages:}

- Regulation on the Protection of Special Nature Reserve supports the development of tourism

- Developing a shared social responsibility through the nurturing of heritage and emphasizing the protection of the Reserve (eg, events support stories of Nature Protection)

Disadvantages

- There are no standards for tourist companies (eg receptive agencies, associations for the development of tourism, local tourism organizations ...)

- Voluntary self-regulation and audit of tourism business are not present

\section{Management techniques regarding visitors}

\section{Advantages:}

- Zoning as a protection regime for the Reserve is used in tourism (I, II and III degree)

- Enclosed parts of the reserve may be easier to control (activating rangers and gamekeepers)

Disadvantages:

- The large surface of the protected area and its elongated shape make it difficult to control

- These techniques are not present: "honeypot«, channeled streams of visitors, limited entries and vehicle restrictions

\section{Environmental Impact Assessment}

Advantages:

- Monitoring the state of the ecosystem and habitats that is implemented each year

- Commitment to Environmental Audit in the plan documents (reserve management plan is regularly adopted)

Disadvantages

- Lack of information about the compatibility of tourism activities and various influences.

- Lack of commitment to the geodiversity and geological heritage

- The absence of proposals to minimize the impact

- No environmental certification

\section{Determining the carrying capacity}

Advantages:

- Current traffic and volume of tourism generally do not threaten the environmental resources (statements about the state of the ecosystem prove this)

Disadvantages:

- Carrying capacity is not determined for the Gornje Podunavlje Reserve

- There is a small degree of control at the sites of excursion resorts (Baračka, Vagoni, Kenđija ...), which are especially burdened

- The scientific methods for testing the impact of tourism on the local communities are not carried out

6. Consultation / techniques and methods of participation Advantages:

- Population take action independently of environmental factors (eg, ethno-house in Bezdan, Bački Monoštor, Kupusina and Sonta)

- Organization of training programs in the field of eco-tourism, and rural tourism (organized several times in Bački Monoštor Kupusina, Sonta and Sombor)

- Information and involvement of local people in cross-border cooperation

Disadvantages:

- Training programs are sporadic and not constant

\section{The codes of ethics}

Advantages:

- Information panels at the entrance to the reserve with a list of permitted and prohibited activities

- Information panels on the ecosystem rehabilitation projects

Disadvantages:

- There is no code of ethics aimed at the tourism industry and the local population

- Tourist marketing is not sufficiently dedicated to codes of ethics

\section{Indicators of Sustainable Tourism}

Advantages:

- Gornje Podunavlje is a destination in its initial stage of development, so the degree of harmful effects of tourism is small.

Disadvantages:

- Lack of an adequate monitoring system 


\section{Conclusion}

Special Nature Reserve Gornje Podunavlje with its immediate surroundings is still a young tourist destination. Gornje Podunavlje has, in terms of self-initiative of the local population, reached its peak and technical assistance is now necessary to enable detailed analysis of resources to ensure that all changes could be tracked in the future in order to prevent what has already happened in numerous affirmed destinations - lack of information on the condition of resources before the tourism development which would be a parameter of change. It is necessary to introduce a clear system of calculating the carrying capacity, because that is exactly what is essential in improving the management of the destination. Finally, if we compare the standards which an eco-tourism destination should meet (Wood 2002), then one can see that the development of tourism has shortcomings that are mentioned in the paper. Solutions should be sought in meeting the principles of sustainable tourism, modeled on the successful destinations.

\section{References}

Blešić, I., Pivac, T., Đorđević, J., Stamenković, I., Janićević, S. 2014: Cultural events as part of cultural tourism development. Case study: Sombor and Apatin (Serbia). Acta geographica Slovenica 54-2. DOI: http://dx.doi.org/10.3986/AGS54406

Boyd, S. 2000: Tourism, national parks and sustainability. Tourism and national parks, Issues and implications. Chichester.

Fennel, D., A. 1999: Ecotourism: An introduction. London.

Folić - Kurtović, N., Medović, P., Kulić, B., Đekić, M. 2008: Kulturno nasleđe Vojvodine. Novi Sad.

Hadžić, O. 2005: Kulturni turizam. Novi Sad.

Hall, M., Page, S. 2002: The geography of tourism and recreation - environment, place and space. London \& New York.

Holden, A. 2000: Environment and Tourism. London \& New York.

Garrod, B., Wornell, R., Youell, R. 2006: Re-conceptualizing rural resources as countryside capital: The case of rural tourism. Journal of rural studies 22. DOI: http://dx.doi.org/10.1016/j.jrurstud.2005.08.001

Indicators of Sustainable Development for Tourism Destinations, A Guidebook. World Tourism Organization. Madrid, 2004.

Ivkov - Džigurski, A., Bubalo - Živković, M., Lukić, T., Dragin, A., Ivanović, Lj, Pašić, M. 2010: Demografski razvoj pograničnih opština Banata u drugoj polovini XX veka. Novi Sad.

Jovičić, D. 2000: Turizam i životna sredina - koncepcija održivog razvoja. Beograd.

Mowforth, M., Munt, I. 2003: Tourism and Sustainability: Development and New Tourism in the Third World. London.

Popis stanovništva, domaćinstava i stanova u Republici Srbiji 2011 - prvi rezultati. Republički zavod za statistiku. Beograd, 2011.

Prato, Fagre, 2005: National parks \& protected areas. Oxford.

Roberts, L., Hall, D. 2001: Rural Tourism and Recreation: Principles to Practice. Wallingford.

Stojanović, V. 2005: Turizam u specijalnim rezervatima prirode Vojvodine. Novi Sad.

Timothy, D. 2000: Tourism and international parks. Tourism and national parks, Issues and implications. Chichester.

Todorović, M., Bjeljac, Ž. 2009: Rural tourism in Serbia as a concept of development in undeveloped regions. Acta Geographica Slovenica 49-2. DOI: http://dx.doi.org/10.3986/AGS49208

Tomić, P., Romelić, J., Kicošev, S., Besermenji, S., Stojanović, V., Pajović, T., Pavić, D. 2002: Cultural Values in the Tourism Offer of Vojvodina. Novi Sad.

Wood, M. E. 2002: Ecotourism: Principles, Practices \& Policies for Sustainability. Paris, Burlington. 